\title{
Technical audit of operations and maintenance needs in the Tlatak irrigation area in East Java's Magetan regency
}

\author{
Yuli K Iswahyudi ${ }^{1, *}$ and Mamok Suprapto ${ }^{2}$ \\ ${ }^{1}$ Graduate Students, Department of Civil Engineering, Universitas Sebelas Maret, Surakarta, \\ Indonesia \\ ${ }^{2}$ Lecturer, Department of Civil Engineering, Universitas Sebelas Maret, Surakarta, Indonesia
}

\begin{abstract}
Irrigation water shortages have the potential to limit agricultural development otherwise arable land. To resolve such irrigation water shortages, accurate evaluations focusing on the assessment of the irrigation system's physical condition, the functionality of the infrastructure components, and the irrigation efficiency are all needed. The assessments of physical condition and functionality are metrics used to establish the performance index value of the irrigation system. The performance index value can be used to identify sections that need maintenance and to define the level of damage that has impacted the irrigation network infrastructure. The irrigation network's overall performance is analyzed based on the weight of each criterion as defined in the Minister of Public Works Regulation No.32 Year 2007. This research location is Tlatak Irrigation Area, in the District of Parang, Magetan Regency. The results of the analysis showed that the efficiency of irrigation was $74.24 \%$, and the irrigation system performance was only $61.11 \%$. These numbers indicate that the Tlatak irrigation network is categorized as 'Requiring Attention.' Efforts should be made to resolve the irrigation issues by conducting periodic maintenance, constructing one or more deep wells, and enhancing the role of the Water User Farmers' Association.
\end{abstract}

\section{Introduction}

\subsection{Background}

Indonesia has tracts of arable land which have the potential to be developed, for example, farm land in Magetan Regency located in East Java. One of the sub districts in Magetan, Parang, has 401 ha-wide non-irrigation rice farms [2]. The farm land located in Parang Sub District relies on the Gonggang Dam for irrigating water through the Bendung Bowong and Bendung Tlatak irrigation networks.

\footnotetext{
*Corresponding author: yulikiswahyudi@gmail.com
} 
Currently, the demands for irrigating water in the Tlatak Irrigation Area are not being met adequately. Considering the information and review conducted, the unmet demands for irrigation water in the irrigation area are impeded by two main issues: illegal diversion, and damages to the irrigation channel infrastructure. The flow rate and duration of illegal diversion is not well documented. Damages to the irrigation channel infrastructure can be studied and evaluated, to identify ways in which optimal water distribution has been impacted.

A comprehensive study or assessment on the Tlatak Irrigation Area had never been conducted prior to the present time. For that reason, this study is vitally important to understanding the conditions affecting the development of farmland in this region.

\subsection{Objectives and benefits}

The objectives to be achieved in this study are to determine the efficiency of irrigation in the Tlatak Irrigation Area, to assess the physical condition and assign functional values to each component of the currently existing infrastructure, and to make recommendations for measures which can be implemented in order to increase the efficiency of irrigation and recover these water resources for the Tlatak irrigational area.

\subsection{Literature review}

Agus Sumadiyono says that the measurement of water efficiency in irrigation channels can be conducted using several different methods: The Puddling method, the Inflow and Outflow method, and the Seepage method. However, in his study, he used the InflowOutflow method to measure efficiency [8].

Water loss is affected by evaporation and seepage factors. However, other factors can also contribute to water loss: illegal tapping and diversion by farmers; irregular operations affecting the consistent flow of water to farming compartments; excessive drainage; and wasteful water use by farmers. Significant water loss along the channel reduces the volume of water available to be utilized in agriculture and results in inefficient irrigation [3].

This assessment of irrigation network performance was conducted based on three components for optimal irrigation management: OP unit cost (IDR/ha/year); irrigation network damages and overall condition of the infrastructure; and water availability and irrigation area width. The final results will be evaluated to determine the implementation of necessary rehabilitation measures, assigned by priority. Those three components hold equal weight; therefore, the total ranking will show the ranking of performance for individual irrigation areas [4].

I'ied Tunas Atmaja suggests that a priority scale with criteria weighting and alternatives will answer the question of which items or sections are prioritized to rehabilitate. Selecting alternative areas for rehabilitation is contingent on available funding and is adjusted accordingly. When the available funding is inadequate, the rehabilitation efforts will be directed to a primary channel only [1].

\section{Research method}

\subsection{Obtaining the irrigation efficiency and performance index values for the Tlatak irrigation area}

The research location identified as the target was the Tlatak Irrigation Area, located in Parang Sub District of Magetan Regency, East Java. The Tlatak Irrigation Area relies on 
Gonggang Dam for irrigation water, and the service area comprises 993 ha. The region covered by the Tlatak Irrigation area has sustained damage to many of the structures composing the total Irrigation Network infrastructure.

Measuring water efficiency in each irrigation channel was conducted using the InflowOutflow method. The network performance ability to distribute irrigation water refers to Public Work Minister's Regulation No.32 of 2007, which specifies that the Performance Index for the Tlatak irrigation area is obtained based on the physical condition and functionality of the irrigation network [5]. By carefully considering the performance index results, the best means of improving the efficiency of the irrigation system can be determined.

\subsection{Irrigation efficiency}

Irrigation efficiency is defined as the ratio of water used to water tapped, expressed in percentage (\%) [7]. This efficiency is calculated based on the volume of water taken and lost in both primary and secondary channels and within rice farming compartments. The formula used to estimate the water loss is expressed in Eq. 1.

$$
\mathrm{B}=\frac{\text { Inflow-Outflow }}{\text { Outflow }} \times 100 \%
$$

where:

$\mathrm{B}=$ water loss during distribution

Inflow $=$ the volume of water inflowing/taken from intake

Outflow $=$ the volume of water released.

The formula for efficiency is expressed in Eq.2.

$$
E c=100 \%-B
$$

where:

Ec = efficiency of irrigation water distribution

$\mathrm{B} \quad=$ water loss during distribution.

\subsection{Assessment of irrigation network performance}

The assessment of irrigation network performance refers to [5]. The Performance Index value for the irrigation system is estimated based on Public Work Minister's Regulation No.32 of 2007 as shown in Table 1.

Table 1. Performance Index of Irrigation System.

\begin{tabular}{|c|c|}
\hline Work Index Value & Performance \\
\hline $80-100$ & Very Good \\
\hline $70-79$ & Good \\
\hline $55-69$ & Poor and requiring attention \\
\hline$<55$ & Bad and requiring attention \\
\hline
\end{tabular}

(Source: Public Work Minister's Regulation No.32 of 2007) 


\subsection{Assessment of the physical condition of the irrigation network infrastructure}

The assessment of the physical condition began with a complete infrastructure inventory to determine the condition of the irrigation network, including the location of any damages sustained, the effect of this damage on the service area, and identification of the precise amount of damage to the overall irrigation network infrastructure. If damage is observed, the usable life of a damaged asset can be extended with such interventions as repair or replacement.

This, the expected life of the asset can actually be extended/re-calculated once the appropriate intervention is completed, as long as the intervention involves the majority of the components of the asset part (that is, major rehabilitation), and the rehabilitation results in measurable improvement, meaning capacity increases to the level predicted by specifications. Classification of the irrigation network's physical condition and recommended maintenance is presented in Table 2.

Table 2. Classification of the Irrigation Network's Physical Condition and Recommended Maintenance.

\begin{tabular}{|c|c|c|}
\hline Damage Level & Condition & Recommended Maintenance \\
\hline$<10 \%$ of Prior Condition & Good & Routine maintenance \\
\hline$<10-20 \%$ of Prior Condition & Mildly damaged & Periodical maintenance \\
\hline$<21-40 \%$ of Prior Condition & Moderately damaged & Repairs Needed \\
\hline$>40 \%$ of Prior Condition & Severely damaged & Major Repair/ Replacement \\
\hline
\end{tabular}

(Source: Public Work Minister's Regulation No. 12 of 2015) [6]

\subsection{Assessment of planting productivity}

\subsubsection{Determining the rice plant's need for water}

Analysis of the rice plant's need for water in a rice farm is affected by several factors: land cultivation, rate of consumption, percolation, water layer replacement, and the effective contribution of rain. The rice plant's need for water is estimated in Eq.3 through Eq.5.

$$
\begin{gathered}
N F R=E T c+P+W L R-R e \\
E T c=k c \times E_{0} \\
E c=100 \%-B
\end{gathered}
$$

where:

$$
\begin{aligned}
& \mathrm{NFR}=\text { water need } \\
& \mathrm{ETc}=\text { the rice plant's need for water } \\
& \mathrm{P} \quad=\text { the rate of percolation } \\
& \mathrm{WLR}=\text { water layer replacement } \\
& \mathrm{Re}=\text { effective rain } \\
& \mathrm{kc} \quad=\text { the plant coefficient } \\
& \mathrm{Et} 0 \quad \text { evapotranspiration }
\end{aligned}
$$

\subsubsection{Determining the crop plant's need for water}

A crop plant's need for water is estimated using Eq.6.

$$
I R=E T c-R e
$$


where:

$\mathrm{IR}=$ the crop plant's need for water

$\mathrm{Re}=$ effective rain

\subsubsection{Effective rain}

Effective rain based on monthly rainfall is R 80 meaning that its incidence impossibility is $20 \%$. Effective rain is estimated using Eq. 7 .

$$
R e=0.7 \times \frac{1}{15}\left(R_{80}\right)
$$

where:

$\mathrm{Re}=$ effective rain

$\mathrm{R} 80=$ effective rainfall

\subsubsection{Evapotranspiration}

Evapotranspiration uses the combination of mass transfer and energy balance or Penman methods. Panman method is presented in Eq.8.

$$
E_{t}=\frac{\Delta E_{n} \gamma E_{0}}{\Delta+\gamma}
$$

where:

Et $=$ potential evapotranspiration

En = depth of evaporation calculated based on the net radiation received by the earth's surface

$\mathrm{E} \quad=$ evapotranspiration

\section{Result and discussion}

\subsection{Analysis on irrigation efficiency}

The Tlatak Irrigation Area is divided into 2 parts: The Left Tlatak Irrigation System is $4627.08 \mathrm{~m}$ long, and the Right Tlatak Irrigation System is $4532.16 \mathrm{~m}$ long. Neither of the two systems have a primary channel. They only have a secondary. Water loss is caused by both seepage and evaporation.

Calculating water loss for the Tlatak system shows an efficiency value of $74,24 \%$. This figure is well below the water loss value specified for a secondary channel, which is $90 \%$. The results of the analysis of the efficiency of Tlatak secondary irrigation channels are presented in Table 3. 
Table 3. Results of the Analysis of the Efficiency of Tlatak Irrigation Channels.

\begin{tabular}{|c|c|c|c|c|}
\hline Channel Name & $\begin{array}{c}\text { Inflow rate } \\
\left(\mathbf{m}^{\mathbf{3} / \mathbf{s})}\right.\end{array}$ & $\begin{array}{c}\text { Water } \\
\mathbf{l o s s}\end{array}$ & $\begin{array}{c}\text { Outflow rate } \\
\mathbf{( \mathbf { m } ^ { \mathbf { 3 } } / \mathbf { s } )}\end{array}$ & $\begin{array}{c}\text { Efficiency } \\
\mathbf{( \% )}\end{array}$ \\
\hline S Sek Tlatak Left Side 1 & 0,631 & 0,058 & 0,573 & 89,82 \\
\hline S Sek Tlatak Left Side 2 & 0,625 & 0,140 & 0,485 & 71,10 \\
\hline S Sek Tlatak Left Side 3 & 0,613 & 0,061 & 0,552 & 88,92 \\
\hline S Sek Tlatak Left Side 4 & 0,603 & 0,162 & 0,441 & 63,17 \\
\hline S Sek Tlatak Left Side 5 & 0,601 & 0,057 & 0,544 & 89,49 \\
\hline S Sek Tlatak Left Side 6 & 0,464 & 0,087 & 0,377 & 77,05 \\
\hline S Sek Tlatak Left Side 7 & 0,393 & 0,078 & 0,315 & 75,08 \\
\hline S Sek Tlatak Left Side 8 & 0,347 & 0,052 & 0,295 & 82,33 \\
\hline S Sek Tlatak Right Side 1 & 0,665 & 0,153 & 0,512 & 70,03 \\
\hline S Sek Tlatak Right Side 2 & 0,661 & 0,069 & 0,592 & 88,41 \\
\hline S Sek Tlatak Right Side 3 & 0,594 & 0,202 & 0,392 & 48,31 \\
\hline S Sek Tlatak Right Side 4 & 0,567 & 0,122 & 0,445 & 72,66 \\
\hline S Sek Tlatak Right Side 5 & 0,439 & 0,110 & 0,329 & 66,61 \\
\hline S Sek Tlatak Right Side 6 & 0,428 & 0,130 & 0,298 & 56,37 \\
\hline \multicolumn{4}{|l|}{ Average }
\end{tabular}

\subsection{Analysis on the performance of irrigation system in Tlatak irrigation area}

The assessment of the irrigation network performance was conducted based on weighted values of all criteria as regulated in [5].

\subsubsection{Condition of the physical infrastructure}

The assessment of the physical infrastructure condition was conducted by tracing the complete Tlatak irrigation network. The infrastructural components surveyed include: the main building, carrier and drainage channels, the building within the channel, the inspection path and office, the service house, and the warehouse. On the Tlatak Dam, there is no mud pouch; therefore the dam and dam gates were evaluated. The assessment of the infrastructure is presented in Table 4.

Table 4. Assessment of the Physical Infrastructure Condition.

\begin{tabular}{|c|l|c|c|}
\hline No & \multicolumn{1}{|c|}{ Item } & Weight Value & Weight Condition Value \\
\hline 1 & Main Building & 13 & 11.37 \\
\hline 2 & Carrier Channel & 10 & 5.20 \\
\hline 3 & Building in Carrier Channel & 9 & 5.69 \\
\hline 4 & Disposing Channel and its Building & 4 & 2.99 \\
\hline 5 & Inspection path (road) & 4 & 2.35 \\
\hline 6 & Office, Housing, and Warehouse & 5 & 2.59 \\
\hline \multicolumn{2}{|c|}{ Total } & 45 & 30.19 \\
\hline
\end{tabular}

\subsubsection{Planting productivity}

The Tlatak Irrigation Area relies on Gonggang Dam for its water source, which is used to irrigate a 626 ha-wide section of farmland. The assessment of agricultural productivity is based on the ability to deliver water on demand, the actual cropland width, and plant productivity. The assessment of agricultural productivity is presented in Table 5. 
Table 5. Assessment of Agricultural Productivity.

\begin{tabular}{|c|c|c|c|}
\hline No & Item & Weight Value & Weight Condition Value \\
\hline 1 & Water need fulfilment & 9 & 0.54 \\
\hline 2 & Actual Planting Width & 4 & 2.87 \\
\hline 3 & Rice Productivity & 2 & 1.32 \\
\hline \multicolumn{2}{|c|}{ Total } & 15 & 4.72 \\
\hline
\end{tabular}

\subsubsection{Supporting media}

The assessment of supporting media included the operational and maintenance equipment, transportation, stationery, and communications media. The assessment of supporting media is presented in Table 6 .

Table 6. Assessment of Supporting Media.

\begin{tabular}{|c|l|c|c|}
\hline No & \multicolumn{1}{|c|}{ Item } & Weight Value & Weight Condition Value \\
\hline 1 & OP equipment & 4 & 3.04 \\
\hline 2 & Transportation & 2 & 0 \\
\hline 3 & Stationery & 2 & 1.64 \\
\hline 4 & Communication media & 2 & 1.80 \\
\hline \multicolumn{2}{|c|}{ Total } & 10 & 6.48 \\
\hline
\end{tabular}

\subsubsection{Personnel organization}

The assessment of personnel organization involves reviewing the OP organizational structure, in order to determine the clear responsibilities and duties, and evaluate the number of personnel, including Civil Servants and non-Civil Servant employees. The assessment of Personnel Organization is presented in Table 7.

Table 7. The Assessment of Personnel Organization.

\begin{tabular}{|c|c|c|c|}
\hline No & Item & Weight Value & Weight Condition Value \\
\hline 1 & OP Organization & 5 & 4.42 \\
\hline 2 & Personnel & 10 & 7.38 \\
\hline & Total & 15 & 11.8 \\
\hline
\end{tabular}

\subsubsection{Documentation}

The assessment of documentation verifies the availability of the Irrigation Area data book, a detailed and accurate map, and charts showing the executives and the network schematics. The assessment of documentation is presented in Table 8 .

Table 8. The Assessment on Documentation.

\begin{tabular}{|c|c|c|c|}
\hline No & Item & Weight Value & Weight Condition Value \\
\hline 1 & Irrigation Area Book Data & 2 & 1.46 \\
\hline 2 & Map and Charts & 3 & 2.40 \\
\hline & Total & 5 & 3.86 \\
\hline
\end{tabular}

\subsubsection{Water user farmer association (P3A)}

The assessment of the Water Users Farmers Association is based on the institutional condition, legal rationale, the number and frequency of meetings held, the level of 
participation by the P3A in repairing, tracing, and allocating water resources, and dues collected. The assessment of the Water Users Farmers Association is presented in Table 9.

Table 9. The Assessment of the Water User Farmers Association.

\begin{tabular}{|c|l|c|c|}
\hline No & \multicolumn{1}{|c|}{ Item } & $\begin{array}{c}\text { Weight } \\
\text { Value }\end{array}$ & $\begin{array}{c}\text { Weight Condition } \\
\text { Value }\end{array}$ \\
\hline 1 & P3A with legal entity & 1.5 & 0.15 \\
\hline 2 & Institutional condition & 0.5 & 0.50 \\
\hline 3 & P3A Meeting & 2 & 0.80 \\
\hline 4 & P3A actively attending the survey & 1 & 0.4 \\
\hline 5 & P3A participation in network repairing & 2 & 0.80 \\
\hline 6 & P3A dues for Tertiary Network Repairing & 2 & 0.80 \\
\hline 7 & $\begin{array}{l}\text { P3A participation in Park Arrangement and Water } \\
\text { Allocation Planning }\end{array}$ & 1 & 0.60 \\
\hline \multicolumn{2}{|c|}{ Total } & 10 & 4.05 \\
\hline
\end{tabular}

\subsubsection{Results of the assessment of the performance of the Tlatak irrigation system}

Public Work Minister's Regulation No.32 of 2002, the conclusion is that the Tlatak Irrigation System is categorized as 'Poor and Needing Attention.' The summary of the comprehensive assessment of the Tlatak Irrigation System performance is presented in Table 10 .

Table 10. Summary of Assessment of the Tlatak Irrigation System Performance Index

\begin{tabular}{|c|l|c|c|}
\hline No & \multicolumn{1}{|c|}{ Item } & Weight Value & Weight Condition Value \\
\hline 1 & Physical infrastructure condition & 45 & 30.19 \\
\hline 2 & Planting productivity & 15 & 4.72 \\
\hline 3 & Supporting Media & 10 & 6.48 \\
\hline 4 & Personnel Organization & 15 & 11.8 \\
\hline 5 & Documentation & 5 & 3.86 \\
\hline 6 & Water User Farmer Association & 10 & 4.05 \\
\hline \multicolumn{2}{|c|}{ Total } & 100 & 61.11 \\
\hline
\end{tabular}

\subsection{Discussion}

The validity of the final result, which has determined Tlatak Irrigation System's efficiency value falls well below the specified value for an efficient system, was confirmed by the low value assessing the physical infrastructure's condition, as exemplified by the carrier channels and the carrier building. This result is also consistent with the field condition of irrigation channels which reveal much damage in the forms of sediment, leakage and holes, sloping, cracking, and scouring. The mean damage level is $18 \%$ of the prior established condition, which was considered mildly damaged. The recommended actionable steps for mildly damaged systems is to continue periodic maintenance.

However, the current performance value of the Tlatak irrigation system belongs to the 'Poor and Requiring-Attention' category. The points which must be further considered in accurately assessing the performance of this irrigation system are: the inadequate supply of water to meet the existing demands, and the role of the Water Users Farmers Association. In terms of ameliorating the insufficiency of the water supplies, Magetan Regency government plans to develop one or more deep wells which will supply additional water resources. In addition to the government's attempt, the role of the Water Users Farmers Association as partners in infrastructure maintenance and resources conservation should be expanded. 


\section{Conclusions}

Considering the results of this research, the discussion about the efficiency of the irrigation water system, and the assessment of the physical condition and functionality of the infrastructure components, the following conclusion must be reached: the efficiency value of the irrigation system is $74,24 \%$, lower than the value of $90 \%$ specified for this type of system in the regulations. Regarding the assessment of overall performance, the performance value of the Tlatak Irrigation system is only 61.11 which categorizes this system as 'Poor and/or Requiring Attention.' The proposed action steps which should be attempted in order to deal with these issues include: periodic maintenance on the irrigation channels to improve their efficiency and mitigate damages caused by sediment, leakage, and holes, etc.; deep well construction to attempt to fulfill existing and future demands on the water supply; and the continued involvement of the Water Users Farmers Association.

The author would like to thank the counselors and civitas academica of the Civil Engineering Postgraduate Program of Sebelas Maret University for helping to complete this research. The opinions, findings, and conclusions or recommendations presented in this material come from the author and do not always reflect on the perspective of any university or college, particularly Sebelas Maret University.

\section{References}

1. Atmaja, T. I'ied, Evaluasi dan Peningkatan Kinerja Jaringan Irigasi Bapang Kabupaten Sragen. Program Studi Megister Teknik Sipil. Universitas Sebelas Maret, Surakarta. (2008)

2. Badan Pusat Statistik of Magetan, (2016)

3. Bancin, A. Andriani, Jayanti, S. Dewi, and T.Ferijal, Efisiensi Penyaluran Air Irigasi BKA Kn 16 Lam Raya Daerah Irigasi Krueng Aceh. Jurnal Rona Teknik Pertanian, VIII (1), pp. 19-28. (2015)

4. N. Fatchan. Performance Analysis of Irrigation Network. AGRITECH Vol 27 No.4. (2007)

5. Peraturan Menteri Pekerjaan Umum Nomor: 32/PRT/M/2007. (2007)

6. Peraturan Menteri Pekerjaan Umum dan Perumahan Rakyat Republik Indonesia Nomor 12/PRT/M/2015. (2015)

7. Standar Perencanaan Irigasi, (2010)

8. A. Sumadiyono, Analisis Efisiensi Pemberian Air di Jaringan Irigasi Karau Kabupaten Barito Timur Provinsi Kalimantan Tengah. Institut Teknologi Bandung, Bandung. (2012) 